\title{
Studies on the folic acid activity of human serum
}

\author{
A. H. WATERS ${ }^{1}$ AND D. L. MOLLIN ${ }^{2}$ \\ With the technical assistance of \\ JOSEPHINE POPE AND THURL TOWLER \\ From the Department of Haematology, Postgraduate Medical School of London ${ }^{3}$
}

SYNOPSIS A method for the measurement of serum folic acid activity is described, which is a modification of previous methods.

The material in serum with activity for $L$. casei is made up of a stable and a labile component. The amount of stable component in normal subjects and patients with megaloblastic anaemia is similar. The amount of labile component varies. In patients with folic acid deficiency none is present; in normal subjects it constitutes between 65 and $94 \%$ of the total serum $L$. casei activity. The labile component appears to be an index of folic acid metabolism, and the assay of total serum $L$. casei activity is therefore a valuable method for differentiating patients requiring treatment with folic acid from normal subjects and patients with primary vitamin $B_{12}$ deficiency. Normal subjects had serum folic acid levels from 5.9 to $21.0 \mathrm{~m} \mu \mathrm{g} . / \mathrm{ml}$. (mean $9.9 \mathrm{~m} \mu \mathrm{g} . / \mathrm{ml}$. $\pm 0.3 \mathrm{~m} \mu \mathrm{g} . / \mathrm{ml}$. S.E.). In patients with megaloblastic anaemia requiring treatment with folic acid, other than megaloblastic anaemia of pregnancy, the levels were less than $4.0 \mathrm{~m} \mu \mathrm{g} . / \mathrm{ml}$. Patients with uncomplicated pernicious anaemia had levels from 6.0 to $27.0 \mathrm{~m} \mu \mathrm{g} . / \mathrm{ml}$. (mean $16.6 \mathrm{~m} \mu \mathrm{g} . / \mathrm{ml}$. $\pm 1.1 \mathrm{~m} \mu \mathrm{g} . / \mathrm{ml}$. S.E.). The mean level in this group was higher than in normal subjects, and the highest levels of all were found in patients with subacute combined degeneration of the cord with minimal anaemia (range 14.4 to $36.8 \mathrm{~m} \mu \mathrm{g} . / \mathrm{ml}$.; mean $24.8 \mathrm{~m} \mu \mathrm{g} . / \mathrm{ml}$. $\pm 2.4 \mathrm{~m} \mu \mathrm{g} . / \mathrm{ml}$. S.E.).

The $L$. casei activity of the labile component is lost during autoclaving or storage at $-20^{\circ} \mathrm{C}$. This loss can be prevented during autoclaving by using adequate amounts of ascorbic acid in the phosphate buffer used to dilute the serum for assay and by adding ascorbic acid to serum that is to be stored. Moreover, the activity lost during the storage of serum not protected by ascorbic acid could be restored, for periods up to three months, by adding ascorbic acid to this serum before assay.

The folic acid activity of blood and serum has been measured in the past by a number of workers using Streptococcus faecalis (Schweigert and Pearson, 1947; Wolff, Drouet, and Karlin, 1949; Toennies and Gallant, 1949; Girdwood, 1953; Nieweg, Faber, de Vries, and Kroese, 1954; Condit and Grob, 1958; and Cox, Meynell, Cooke, and Gaddie, 1960) and/or Lactobacillus casei (Schweigert, 1948; Simpson and Schweigert, 1949; Spray, 1952; and Spray and Witts, 1952) as test organisms. These workers were unable to demonstrate a consistent difference in the levels of folic acid activity of blood or serum in normal

\footnotetext{
${ }^{1}$ University of Queensland Travelling Scholar in Medicine.

${ }^{2}$ In receipt of a grant from the Medical Research Council.

${ }^{3}$ Postal address: Ducane Road, London, W.12.

Received for publication 5 June 1961.
}

subjects, patients with vitamin $B_{12}$ deficiency, and patients with folic acid deficiency, and the results suggested that patients with folic acid deficiency could not be differentiated by measuring the level of folic acid activity in blood or serum.

However, Toennies, Frank, and Gallant (1953) and Toennies, Usdin, and Phillips (1956) showed that the folic acid material in blood was heat-labile and could be preserved for assay either by dialysis at low temperature or by autoclaving in the presence of ascorbic acid. Using these methods they found that the folic acid activity of blood for $L$. casei was 20 to 100 times as high as previously reported, and Grossowicz, Aronovitch, Rachmilewicz, Izak, Sadovsky, and Bercovici (1960) used a modification of this method to measure the blood 'folic acid' levels of mothers and newborn infants at term. 
Baker, Herbert, Frank, Pasher, Hutner, Wasserman, and Sobotka (1959) used a modification of this method to measure the folic acid activity of serum. They found that patients with folic acid deficiency had lower levels of serum folic acid activity than normal subjects or patients with uncomplicated vitamin $\mathbf{B}_{12}$ deficiency.

Using the method of Baker et al. (1959), we found a considerable overlap between the results in normal subjects and patients with folic acid deficiency. There was also a wide variation in results between different batches. The diagnostic value of the method as described by Baker et al. (1959) was therefore of limited value in our hands. It seemed likely that the labile folic acid material was being inadequately protected by the method as we were using it. We therefore studied the factors affecting the preservation of folic acid active material in serum with a view to improving the diagnostic value of the assay. The results of these studies are reported and a modified assay procedure is described.

\section{MATERIALS AND METHODS}

\section{BASAL MEDIUM}

A modification of the basal medium of Jukes (1955) was used (Table I). A vitamin-free enzymatic casein hydrolysate was used in preference to acid hydrolysed casein (Difco, Oxoid) and salt-free hydrolysed casein (B.B.L.), because both of these preparations gave a precipitate

\section{TABLE I}

DOUBLE STRENGTH BASAL MEDIUM ( $p \mathrm{H} 6 \cdot 6-6 \cdot 8)$

\begin{tabular}{|c|c|c|}
\hline Reagents & $\begin{array}{l}\text { Concentro } \\
\text { (per litre) }\end{array}$ & ation \\
\hline Enzymatic casein hydrolysate ${ }^{1}$ & 200 & ml. \\
\hline Adenine sulphate & 10 & mg. \\
\hline Guanine hydrochloride & 10 & mg. \\
\hline Uracil & 10 & mg. \\
\hline Xanthine & 20 & mg. \\
\hline L-aspargine monohydrate & 600 & mg. \\
\hline L-cysteine hydrochloride & 500 & mg. \\
\hline Riboflavin & 1 & mg. \\
\hline p-Amino-benzoic acid & 2 & mg. \\
\hline Pyridoxine hydrochloride & 4 & mg. \\
\hline Thiamine hydrochloride & 0.4 & mg. \\
\hline Calcium pantothenate & 0.8 & mg. \\
\hline Nicotinic acid & 0.8 & mg. \\
\hline Biotin & 0.02 & mg. \\
\hline Dextrose (anhydrous) & 40 & g. \\
\hline Tween 80 solution $(0.5 \%)$ & 20 & ml. \\
\hline Glutathione (reduced) & 5 & mg. \\
\hline Salt solution $^{2}$ & 10 & mi. \\
\hline Sodium acetate (anhydrous) & 40 & g. \\
\hline $\mathrm{K}_{2} \mathrm{HPO}_{4}$ & 1 & g. \\
\hline $\begin{array}{l}\mathrm{KH}_{2} \mathrm{PO}_{4} \\
\mathrm{MnSO}_{4}, \mathrm{H}_{2} \mathrm{O} \text { (added after } p \mathrm{H} \text { adjusted) }\end{array}$ & $\begin{array}{r}1 \\
200\end{array}$ & $\begin{array}{l}\text { g. } \\
\text { mg. }\end{array}$ \\
\hline
\end{tabular}

'Sterile $5 \%$ solution of enzyme-hydrolysed vitamin-free casein (Nutritional Biochemicals Corporation, Cleveland, Ohio).

${ }^{2}$ One millilitre contains $40 \mathrm{mg}$. $\mathrm{MgSO}_{4}, 7 \mathrm{H}_{2} \mathrm{O} ; 2 \mathrm{mg}$. $\mathrm{NaCl} ; 2 \mathrm{mg}$. $\mathrm{FeSO}_{4}, 7 \mathrm{H}_{2} \mathrm{O} ; 1.5 \mathrm{mg}$. $\mathrm{MnSO}_{4}, \mathrm{H}_{2} \mathrm{O}$. after autoclaving which did not clear on cooling. When the enzymatic casein hydrolysate was used, additional tryptophane was found to be unnecessary.

One batch of a 'dry-mix' medium (B.B.L. folic acid assay medium, special lot 009-607) containing a salt-free acid hydrolysate of casein was also tried. This also gave a precipitate after autoclaving. Nevertheless, it was otherwise satisfactory and would be a convenient medium if small numbers of sera are to be assayed.

This double-strength liquid basal medium was stable when stored in an amber bottle in the refrigerator.

\section{MAINTENANCE OF THE STOCK CULTURE}

The organism used was Lactobacillus casei (ATCC 7469.) This was maintained in dried gelatin discs (Stamp, 1947; Chanarin, Anderson, and Mollin, 1958) and stored in a desiccator over phosphorus pentoxide at room temperature.

Under these conditions the organism remained folic acid dependent and the growth in the control tubes, to which no folic acid was added, was less than $20 \%$ of the highest response in the standard tubes.

\section{PREPARATION OF THE INOCULUM}

A fresh gelatin disc containing the dried organisms was used for each assay. This was incubated in $10 \mathrm{ml}$. of Difco microinoculum broth for 30 hours at $37^{\circ} \mathrm{C}$. The bacterial suspension was then centrifuged, the supernatant decanted off, and the bacterial cells washed in $20 \mathrm{ml}$. of singlestrength basal medium. Finally, the cells were suspended in $20 \mathrm{ml}$. of single-strength basal medium to provide an inoculum of standard optical density (approximately 0.04). One drop of this inoculum was delivered to each assay tube with a Pasteur pipette ( 50 drops $/ \mathrm{ml}$.).

The inoculum was plated on a blood agar plate and incubated with the assay batch to detect any contaminants.

\section{COLLECTION OF SERUM SAMPLES}

Venous blood was collected from subjects at least two hours after food, and allowed to clot at room temperature for approximately two hours. Serum was separated, care being taken to prevent haemolysis, because it was found that varying degrees of haemolysis increased the folic acid activity from three to ten times that of unhaemolysed serum (unpublished observations). The serum was then stored at $-20^{\circ} \mathrm{C}$. until assayed.

\section{STANDARD FOLIC ACID SOLUTION}

A highly purified crystalline preparation of pteroylglutamic acid was used in preparing the standard curve $\overparen{\Phi}$ for each assay, as described by Jukes (1955). Because of $\stackrel{\mathscr{\rho}}{\rightarrow}$ the wide range of concentrations of folic acid used in $T$ preparing the standard solutions, special safeguards against contamination were taken. Volumetric flasks and pipettes were soaked in chromic-sulphuric fluid, thoroughly rinsed in tap water and finally in distilled water. Moreover, containers were marked and kept for the same concentration of folic acid. 


\section{DE-IONIZED WATER}

An Elgastat de-ioniser (type B 107) with Elgalite mixedbed resin (C 403) was used with glass-distilled water.

De-ionized water was used throughout for the preparation of medium and buffer and for the aqueous dilution of serum.

\section{ASSAY PROCEDURE}

\section{PREPARATION OF SERUM}

Sera were prepared for assay by a modification of previous methods (Toennies et al., 1956; Baker et al., 1959).

Sera were, however, diluted $1: 10$ with a $0 \cdot 1 \mathrm{M}$. phosphate buffer of $p \mathrm{H} 6 \cdot 1$. This buffer concentration has been shown to give the optimum yield of folic acid activity for L. casei (Dawbarn, Hine, and Smith, 1958). Various concentrations of ascorbic acid were used in the phosphate buffer (see results); the optimum concentration was found to be $100 \mathrm{mg}$. $\%$.

The 1:10 serum-buffer solution was autoclaved for two and a half minutes at 15 p.s.i. which was adequate to coagulate the serum proteins. The coagulum was spun down and the clear supernatant diluted 1:4 with deionized water, giving a 1:40 dilution of the original serum.

\section{METHOD}

The assay was carried out in a total volume of $4 \mathrm{ml}$. per tube. This volume was selected because, when a serum dilution of $1: 40$ was used, only $0.5 \mathrm{ml}$. of serum was required for each assay. It was also convenient for use with the $1 \mathrm{~cm}$. cell of the Unicam colorimeter.

Two millilitres of the 1:40 serum dilution were added to each of four $6 \times \frac{3}{4}$ in. Pyrex test tubes. Two millilitres of the double-strength basal medium were delivered to each tube by means of an automatic pipetting device, resulting in a final dilution of $1: 80$ of the original serum. The tubes were then closed with aluminium caps, and autoclaved at 10 p.s.i. for 10 minutes, which provided safe sterilization for this assay.

After cooling, one of the four tubes of each serum specimen was set aside as a blank, and the remaining tubes were placed at random in wooden test-tube racks and inoculated with one drop of the prepared inoculum of $L$. casei. The assay batch was then incubated at $37^{\circ} \mathrm{C} . \pm$ $1^{\circ} \mathrm{C}$. for 18 hours.

\section{STANDARD CURVE}

A standard curve was included in each assay. Tubes containing $0 \cdot 0,0 \cdot 1,0 \cdot 2,0 \cdot 4,0 \cdot 6,0 \cdot 8,1 \cdot 0,1 \cdot 2$, and $1.4 \mathrm{~m} \mu \mathrm{g}$. of folic acid were set up in triplicate, as well as one uninoculated blank tube containing no folic acid (Jukes, 1955). The standard tubes were scattered at random among the other assay tubes.

\section{READING AND CALCULATING RESULTS}

Growth was read by measuring turbidity in a Unicam photoelectric colorimeter, using an Ilford 625 filter $(\lambda=$

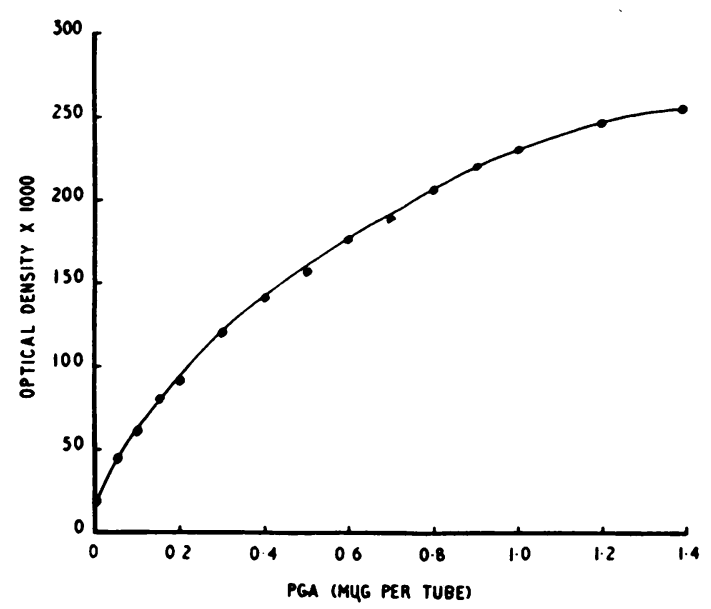

Fig. 1. A representative standard curve for the $\mathrm{L}$. casei assay.

510 to $590 \mathrm{~m} \mu$.), and was recorded in optical density units (O.D. $\times 1,000)$. Each serum sample was read against its own blank which was used to 'zero' the colorimeter. This procedure eliminated the colour effects of the medium and measured only the turbidity due to the growth of $L$. casei. The same procedure was followed with the standard tubes.

The growth densities of the folic acid standards were plotted on arithmetic graph paper against the amount of folic acid per tube. A representative standard curve is shown in Fig. 1. The most sensitive range of the curve is between 0.1 and $1.0 \mathrm{~m} \mu \mathrm{g}$. per tube $(0.025-0.25 \mathrm{~m} \mu \mathrm{g} . / \mathrm{ml}$.), which corresponds to a range of serum folic acid activity from 2.0 to $20.0 \mathrm{~m} \mu \mathrm{g}$./ml., when a 1:80 dilution of the original serum is used. If the serum folic acid activity was lower than $2.0 \mathrm{~m} \mu \mathrm{g}$. $/ \mathrm{ml}$. or greater than $20.0 \mathrm{~m} \mu \mathrm{g}$. $/ \mathrm{ml}$., the specimen was re-assayed at a lower or higher dilution to give readings on the sensitive part of the curve.

\section{CARE OF GLASSWARE}

Scrupulous care of glassware was essential to avoid folic acid contamination.

Test tubes were rinsed in tap water and boiled in a detergent (Pyroneg). ${ }^{1}$ They were then well rinsed with distilled water and packed into wire baskets to drain. All tubes were then filled with distilled water, autoclaved at 15 p.s.i. for 15 minutes, emptied, refilled with distilled water, and autoclaved again. The tubes were then dried, closed with aluminium caps, and sterilised at $160^{\circ} \mathrm{C}$. for one hour.

Aluminium caps were rinsed in tap water, boiled twice in distilled water, and then dried in a hot air oven.

Pipettes were allowed to stand in detergent and were then washed in running tap water overnight, rinsed through with distilled water, and dried with acetone.

${ }^{2}$ Pyroneg is distributed by Deosan Ltd., 42-46 Weymouth Road, London, W.1. 
Flasks, beakers, and measuring cylinders were cleaned with chromic-sulphuric fluid, washed well in running tap water, and finally rinsed with distilled water.

Glassware used in the assay may be kept under ultraviolet light, which results in the photolytic degradation of folic acid (Stokstad, Fordham, and de Grunigen, 1947; Toennies et al., 1953).

\section{SUBJECTS STUDIED}

Serum folic acid activity was measured in the following groups of subjects: (1) One hundred normal subjects who were students or members of the staff of the Postgraduate Medical School of London; (2) 42 patients with untreated Addisonian pernicious anaemia, and nine patients with pernicious anaemia in remission following vitamin $\mathbf{B}_{12}$ therapy; (3) 22 patients with megaloblastic anaemia of pregnancy and 16 normal pregnant women; (4) 15 patients with untreated idiopathic steatorrhoea, showing evidence of malabsorption with a typically abnormal jejunal biospy appearance; (5) seven patients with nutritional folic acid deficiency. This diagnosis was restricted to patients with a megaloblastic anaemia with a normal serum vitamin $\mathrm{B}_{12}$ level, a poor dietary history, no history of taking anticonvulsant drugs, normal absorption of fat, glucose, folic acid, and $\mathrm{B}_{12}$, and no histological or radiological evidence of an intestinal lesion.

\section{RESULTS}

THE EFFECT OF ASCORBIC ACID ON THE FOLIC ACID ACTIVITY OF SERUM

EFFECT OF ASCORBATE BUFFER ON THE STANDARD CURVE To determine the effect of ascorbate buffer on the growth of $L$. case $i$ in the standard tubes, a control set of standards was set up containing $2 \mathrm{ml}$. of an aqueous solution of pteroylglutamic acid (PGA) covering a range of 0 to $1.0 \mathrm{~m} \mu \mathrm{g}$. per tube and $2 \mathrm{ml}$. of double-strength medium. This was compared with a series of tubes which contained (1) $1.55 \mathrm{ml}$. of aqueous PGA solution covering the same range of $P G A$ as the standard tubes, (2) $0.45 \mathrm{ml}$. of ascorbate-phosphate buffer containing either 50 , 100 , or $150 \mathrm{mg}$. $\%$ of ascorbic acid, and (3) $2 \mathrm{ml}$. of double-strength medium. This is the amount of buffer contained in the serum tubes during assay. To ensure that conditions in this experiment were the same as in the assay, the ascorbate buffer was autoclaved for two and a half minutes at 15 p.s.i. before it was added to the standard tubes.

The optical density readings at each PGA concentration level are given in Table II. The ascorbate buffer had no effect on the growth of the $L$. casei standards over the range of PGA concentrations used (0-0.25 $\mathrm{m} \mu \mathrm{g}$. per $\mathrm{ml}$.).
TABLE II

EFFECT OF ASCORBIC ACID ON THE GROWTH OF L. CASEI

\begin{tabular}{|c|c|c|c|c|}
\hline $\begin{array}{l}P G A \\
(m \mu g . / t u b e)\end{array}$ & $\begin{array}{l}\text { No } \\
\text { Ascorbate } \\
\text { Buffer }\end{array}$ & $\begin{array}{l}50 \mathrm{mg} . \% \\
\text { Ascorbate } \\
\text { Buffer }\end{array}$ & $\begin{array}{l}100 \mathrm{mg} . \% \\
\text { Ascorbate } \\
\text { Buffer }\end{array}$ & $\begin{array}{l}150 \text { mg. } \% \\
\text { Ascorbate } \\
\text { Buffer }\end{array}$ \\
\hline 0 & $20^{1}$ & 30 & 25 & 30 \\
\hline 0.1 & 60 & 60 & 60 & 65 \\
\hline $0 \cdot 15$ & 80 & 80 & 85 & 80 \\
\hline 0.2 & 95 & 100 & 90 & 100 \\
\hline 0.3 & 125 & 125 & 120 & 125 \\
\hline 0.4 & 140 & 135 & 135 & 140 \\
\hline 0.5 & 160 & 165 & 160 & 155 \\
\hline 0.6 & 170 & 175 & 175 & 170 \\
\hline 0.7 & 190 & 190 & 185 & 195 \\
\hline 0.8 & 200 & 200 & 205 & 210 \\
\hline 0.9 & 220 & 210 & 215 & 220 \\
\hline 1.0 & 220 & 220 & 230 & 230 \\
\hline
\end{tabular}

EFFECT OF ASCORBIC ACID ON SERUM FOLIC ACID ACTIVITY To study the effect of ascorbic acid on serum folic acid activity, fresh sera from normal controls were prepared for assay, using concentrations from 0 to $150 \mathrm{mg}$. \% of ascorbic acid in the phosphate buffer. The results are given in Table III.

TABLE III

EFFECT OF ASCORBIC ACID ON THE FOLIC ACID ACTIVITY OF SEVEN NORMAL SERA ${ }^{1}$

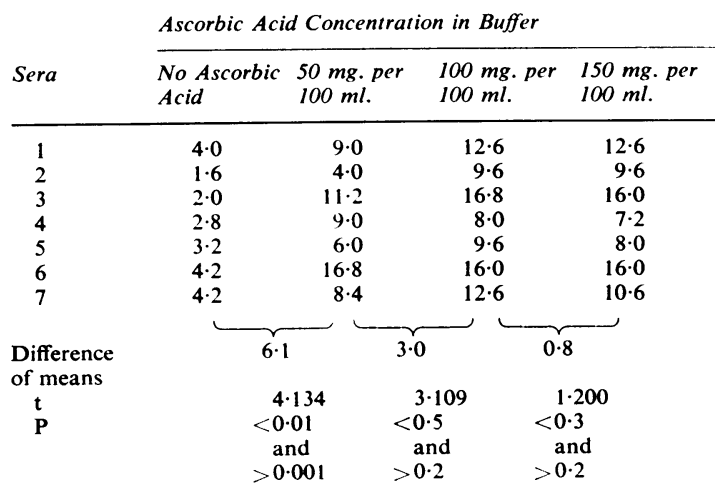

${ }^{1}$ Results expressed in $\mathrm{m} \mu \mathrm{g} . / \mathrm{ml}$.

In the absence of ascorbic acid, serum folic acid activity ranged from 1.6 to $4.2 \mathrm{~m} \mu \mathrm{g} . / \mathrm{ml}$. When $\stackrel{\mathbb{D}}{\circ}$ ascorbic acid was added to the phosphate buffer the ? serum folic acid activity increased significantly. A constant level of serum folic acid activity was obtained when the ascorbic acid concentration in the buffer was $100 \mathrm{mg}$. \%.

The importance of using the optimal concentration of ascorbic acid in the buffer is shown in Table IV. This compares the folic acid levels obtained when

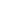


TABLE IV

EFFECT OF HEAT ON SERUM FOLIC ACID ACTIVITY OF NORMAL SUBJECTS AND PATIENTS WITH FOLIC ACID DEFICIENCY

\begin{tabular}{|c|c|c|c|c|c|}
\hline Condition & Sera & $\begin{array}{l}\text { Stable } \\
(S)\end{array}$ & $\begin{array}{l}\text { Total } \\
(T)\end{array}$ & $\begin{array}{c}\text { Labile } \\
(T-S)\end{array}$ & $\frac{L}{T} \times 100 \%$ \\
\hline \multirow[t]{2}{*}{ Normal subjects } & $\begin{array}{r}1 \\
2 \\
3 \\
4 \\
5 \\
6 \\
7 \\
8 \\
9 \\
10 \\
11 \\
12 \\
13 \\
14 \\
15\end{array}$ & $\begin{array}{l}4.0 \\
1 \cdot 6 \\
2.0 \\
2.8 \\
3 \cdot 2 \\
2.0 \\
1 \cdot 8 \\
2 \cdot 2 \\
1 \cdot 0 \\
1 \cdot 2 \\
2.0 \\
1 \cdot 6 \\
1 \cdot 4 \\
2.2 \\
4.0\end{array}$ & $\begin{array}{r}12.6 \\
9.6 \\
16.8 \\
8.0 \\
9.6 \\
9.0 \\
9.6 \\
8.0 \\
10.0 \\
8.0 \\
5.9 \\
7.6 \\
11.4 \\
7.0 \\
18.0\end{array}$ & $\begin{array}{r}8.6 \\
8.0 \\
14.8 \\
5 \cdot 2 \\
6.4 \\
7 \cdot 0 \\
7 \cdot 8 \\
5.8 \\
9 \cdot 0 \\
6.8 \\
3.9 \\
6.0 \\
10.0 \\
4.8 \\
14.0\end{array}$ & $\begin{array}{l}68 \\
83 \\
94 \\
65 \\
67 \\
78 \\
81 \\
73 \\
90 \\
85 \\
66 \\
79 \\
88 \\
69 \\
78\end{array}$ \\
\hline & $\begin{array}{l}\text { Mean } \\
\text { S.E. }\end{array}$ & $\begin{array}{l}2 \cdot 2 \\
0 \cdot 2\end{array}$ & $\begin{array}{r}10.1 \\
0.5\end{array}$ & $\begin{array}{l}7 \cdot 9 \\
0.8\end{array}$ & $\begin{array}{r}77 \cdot 6 \\
6 \cdot 1\end{array}$ \\
\hline \multirow[t]{2}{*}{ Folic acid deficiency } & $\begin{array}{l}16 \\
17 \\
18 \\
19 \\
20 \\
21\end{array}$ & $\begin{array}{l}2.8 \\
2.0 \\
2.4 \\
2.6 \\
2.6 \\
2.6\end{array}$ & $\begin{array}{l}3 \cdot 0 \\
2 \cdot 4 \\
2 \cdot 5 \\
3 \cdot 2 \\
3 \cdot 5 \\
2 \cdot 6\end{array}$ & & \\
\hline & $\begin{array}{l}\text { Mean } \\
\text { S.E. }\end{array}$ & $\begin{array}{l}2 \cdot 5 \\
0 \cdot 1\end{array}$ & $\begin{array}{l}2 \cdot 9 \\
0 \cdot 2\end{array}$ & & \\
\hline
\end{tabular}

sera from 15 normal subjects and six patients with folic acid deficiency were assayed with and without ascorbic acid in the buffer.

In the absence of ascorbic acid there was no significant difference $(P>0.4)$ between the levels obtained in normal controls and cases of folic acid deficiency. However, when the optimum concentration of ascorbic acid was used in the phosphate buffer there was a highly significant increase $(P<0.001)$ in the serum folic acid activity of the normal control group, but no significant change $(P>0.6)$ in the serum folic acid activity of the folic acid-deficient group.

EFFECT OF STORAGE AT $-20^{\circ} \mathrm{C}$. ON SERUM FOLIC ACID ACrIVITY To study the effect of storage at $-20^{\circ} \mathrm{C}$. on serum folic acid activity, sera from normal control subjects were assayed within $\mathbf{4 8}$ hours of being taken and again one week, three weeks, and three months later. The results are given in Table $\mathrm{V}$. This shows that after one week the residual serum folic acid activity was only $75 \%$ of its original value, after three weeks $67 \%$, and after three months $64 \%$.

There was no significant difference in the folic acid activity of sera from six folic acid-deficient patients after three months' storage.

EFFECT OF STORAGE WITH ASCORBIC ACID ON SERUM FOLIC ACID ACTIVITY Fresh serum from normal subjects was divided into two portions. To one portion was added either dry ascorbic acid $(5 \mathrm{mg}$. per ml. of serum) or an equal volume of $0.1 \mathrm{M}$

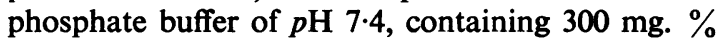
of ascorbic acid. The treated and untreated samples were assayed by the standard procedure using a concentration of $100 \mathrm{mg} . \%$ of ascorbic acid in the buffer within 48 hours of being collected, then all samples were stored at $-20^{\circ} \mathrm{C}$. for three months and re-assayed. The results of these experiments are given in Table VI.

Adding ascorbic acid to fresh serum prevented the loss of folic acid activity during storage, there being no significant difference between the folic acid activity of fresh and stored serum (0.4 $>\mathrm{P}>0.3)$. However, the added ascorbic acid had no effect on the folic acid activity of fresh serum (0.8 $>$ P $>0.7)$.

Some sera were stored with higher concentrations of ascorbic acid. It was found that the protective effect of ascorbic acid was the same with concentrations between 5 and $15 \mathrm{mg}$. per ml. of serum, but higher concentrations interfered with the preparation of sera for assay by lowering the $p \mathrm{H}$ and thereby preventing the coagulation of serum proteins during autoclaving.

EFFECT OF ASCORBIC ACID ON FOLIC ACID ACTIVITY OF STORED SERUM To determine whether the lost folic acid activity of stored serum could be restored by the subsequent addition of relatively large amounts of

TABLE V

LOSS OF SERUM FOLIC ACID ACTIVITY DURING STORAGE AT $-20^{\circ} \mathrm{C}$.

\begin{tabular}{|c|c|c|c|c|c|c|c|}
\hline \multirow[t]{2}{*}{ Classification } & \multirow{2}{*}{$\begin{array}{l}\text { Number } \\
\text { of } \\
\text { Subjects }\end{array}$} & \multicolumn{4}{|c|}{$\begin{array}{l}\text { Serum Folic Acid Activity } \\
\text { (mean } \pm \text { S.E. } m \mu g . / m l .)\end{array}$} & \multirow{2}{*}{$\begin{array}{l}\text { Percentage of } \\
\text { Initial Folic } \\
\text {-Acid Activity } \\
\text { Remaining } \\
\text { (mean } \pm \text { S.E. \%) }\end{array}$} & \multirow[t]{2}{*}{$\begin{array}{l}\text { Significance of } \\
\text { the Differences }\end{array}$} \\
\hline & & Fresh & One Week & Three Weeks & Three Months & & \\
\hline Severe folic acid deficiency & $\begin{array}{r}30 \\
10 \\
23 \\
6\end{array}$ & $\begin{array}{r}9.7 \pm 0.7 \\
10.6 \pm 1.2 \\
10.3 \pm 0.5 \\
2.8 \pm 0.2\end{array}$ & $\begin{array}{c}7.4 \pm 0.5 \\
- \\
-\end{array}$ & $\begin{array}{c}7 \cdot 1 \pm 0.9 \\
= \\
=\end{array}$ & $\begin{array}{c}- \\
6 \cdot 5 \pm 0.3 \\
2 \cdot 2 \pm 0.2\end{array}$ & $\begin{array}{c}75 \cdot 8 \pm 2 \cdot 6 \\
67 \cdot 2 \pm 3 \cdot 7 \\
64 \cdot 1 \pm 3 \cdot 4 \\
-\end{array}$ & $\begin{array}{l}<0.001 \\
<0.05,>0.02 \\
<0.001 \\
>0.6\end{array}$ \\
\hline
\end{tabular}




\section{TABLE VI}

EFFECT OF ASCORBIC ACID ON THE FOLIC ACID ACTIVITY OF SERUM DURING STORAGE AT $-20^{\circ} \mathrm{C}$.

\begin{tabular}{|c|c|c|c|c|}
\hline \multirow[b]{2}{*}{ Sera } & \multicolumn{2}{|l|}{ Fresh } & \multicolumn{2}{|c|}{ Three Months Old } \\
\hline & $\begin{array}{l}\text { No Ascorbic } \\
\text { Acid }\end{array}$ & $\begin{array}{l}\text { With Ascorbic } \\
\text { Acid }\end{array}$ & $\begin{array}{l}\text { No Ascorbic } \\
\text { Acid }\end{array}$ & $\begin{array}{l}\text { With Ascorbic } \\
\text { Acid }\end{array}$ \\
\hline \multicolumn{5}{|c|}{1 Adding Dry Ascorbic Acid to Fresh Serum (5mg. per ml.) } \\
\hline 1 & $13 \cdot 2$ & $13 \cdot 5$ & $7 \cdot 4$ & $14 \cdot 0$ \\
\hline 2 & $16 \cdot 0$ & $15 \cdot 5$ & $8 \cdot 4$ & $16 \cdot 0$ \\
\hline 3 & $6 \cdot 3$ & $6 \cdot 7$ & 3.6 & $6 \cdot 8$ \\
\hline 4 & $8 \cdot 4$ & 8.0 & $5 \cdot 8$ & $8 \cdot 0$ \\
\hline 5 & $7 \cdot 5$ & $7 \cdot 0$ & $5 \cdot 0$ & $8 \cdot 0$ \\
\hline 6 & $8 \cdot 0$ & $9 \cdot 0$ & 6.6 & $8 \cdot 0$ \\
\hline 7 & $10 \cdot 8$ & 9.5 & $7 \cdot 2$ & $10 \cdot 0$ \\
\hline 8 & $10 \cdot 0$ & $9 \cdot 8$ & $5 \cdot 2$ & $10 \cdot 8$ \\
\hline 9 & $8 \cdot 3$ & $7 \cdot 8$ & $4 \cdot 4$ & $8 \cdot 4$ \\
\hline 10 & $10 \cdot 5$ & $10 \cdot 3$ & 6.0 & $12 \cdot 8$ \\
\hline 11 & $11 \cdot 0$ & $12 \cdot 5$ & $6 \cdot 8$ & 13.6 \\
\hline 12 & $10 \cdot 5$ & $9 \cdot 8$ & 6.4 & 10.4 \\
\hline 13 & $9 \cdot 3$ & 9.6 & $5 \cdot 2$ & $10 \cdot 4$ \\
\hline 14 & $10 \cdot 8$ & 10.0 & $7 \cdot 4$ & 10.8 \\
\hline 15 & $10 \cdot 3$ & $9 \cdot 8$ & $7 \cdot 2$ & $12 \cdot 8$ \\
\hline 16 & $11 \cdot 3$ & $11 \cdot 3$ & $7 \cdot 4$ & $12 \cdot 8$ \\
\hline
\end{tabular}

2 Adding Equal Volume of Ascorbate-phosphate Buffer (300 mg. \% ascorbic acid) to Fresh Serum

$\begin{array}{lrrrr}\text { 17 } & 10.5 & 10.0 & 7.5 & 11 \cdot 1 \\ 18 & 14.0 & 18.0 & 8.8 & 16.0 \\ 19 & 6.4 & 7.0 & 4.4 & 6.6 \\ 20 & 8.5 & 8.0 & 5.7 & 8.0 \\ 21 & 10.4 & 12.0 & 8.6 & 12.8 \\ 22 & 12.0 & 13.2 & 8.2 & 13.4 \\ 23 & 13.2 & 13.5 & 7.2 & 12.4\end{array}$

ascorbic acid, dry ascorbic acid ( $5 \mathrm{mg} . / \mathrm{ml}$. of serum) was added to a portion of the untreated serum that had been stored at $-20^{\circ} \mathrm{C}$. for three months (see Table VI), and the folic acid activity was assayed by the standard procedure. The folic acid activity of sera treated in this way is compared in Table VII with the folic acid activity of fresh serum and serum stored alone at $-20^{\circ} \mathrm{C}$. for three months. There was no significant difference $(0.4>\mathrm{P}>0.3)$ between the levels obtained in fresh serum and serum treated in this way.
TABLE VII

EFFECT OF ADDING ASCORBIC ACID TO SERA STORED FOR THREE MONTHS AT $-20^{\circ} \mathrm{C}$. IMMEDIATELY BEFORE ASSAY

\begin{tabular}{|c|c|c|c|c|}
\hline \multirow[b]{2}{*}{ Sera } & \multirow[b]{2}{*}{ Fresh } & \multicolumn{3}{|c|}{ After Storage for Three Months at $-20^{\circ} \mathrm{C}$. } \\
\hline & & $\begin{array}{l}\text { Stored without } \\
\text { Ascorbic Acid }\end{array}$ & $\begin{array}{l}\text { Stored with } \\
\text { Ascorbic Acid }\end{array}$ & $\begin{array}{l}\text { Ascorbic Acid } \\
\text { Added to Stored } \\
\text { Serum } \\
\text { Immediately } \\
\text { before Assay }\end{array}$ \\
\hline $\begin{array}{l}1 \\
2 \\
3 \\
4 \\
5 \\
6 \\
7 \\
8\end{array}$ & $\begin{array}{r}11 \cdot 0 \\
9.5 \\
10.5 \\
14 \cdot 0 \\
9.1 \\
13 \cdot 0 \\
12.0 \\
13 \cdot 2\end{array}$ & $\begin{array}{r}5 \cdot 2 \\
6 \cdot 4 \\
7 \cdot 4 \\
10 \cdot 4 \\
7 \cdot 4 \\
7 \cdot 2 \\
7 \cdot 4 \\
6 \cdot 8\end{array}$ & $\begin{array}{l}10.4 \\
10.4 \\
10.4 \\
16.0 \\
10.8 \\
12.8 \\
12.8 \\
13.6\end{array}$ & $\begin{array}{r}7.4 \\
10.4 \\
10.0 \\
14.0 \\
8.4 \\
10.8 \\
12.0 \\
11 \cdot 2\end{array}$ \\
\hline
\end{tabular}

\section{ACCURACY OF THE METHOD}

The following experiments were carried out to determine the accuracy of the standard method described.

RECOVERY OF PGA ADDED TO POOLED 'LOW' SERUM Because the nature of serum folic acid activity is unknown, recovery experiments cannot strictly be carried out. However, the results (Table VIII) show that by this method there is a good recovery of PGA added to serum. When $10 \mathrm{~m} \mu \mathrm{g}$. $/ \mathrm{ml}$. of PGA was added to pooled 'low' serum the mean recovery was $113.4 \% \pm 4.7 \%$ S.E., and when $20 \mathrm{~m} \mu \mathrm{g}$. $/ \mathrm{ml}$. was added the mean recovery was $99.0 \% \pm 4.3 \%$ S.E.

VARIATION BETWEEN DIFFERENT ASSAYS This was studied by repeated assays on the same two 'control' sera in eight consecutive assays. The results (Table IX), show that with the 'high' control the coefficient of variation was $10.8 \%$ and with the 'low' control $18.2 \%$.

\begin{tabular}{|c|c|c|c|c|c|}
\hline \multirow{2}{*}{ Assay No. } & \multicolumn{5}{|c|}{ L. casei Activity $(m \mu g . / m l)}$. \\
\hline & Pooled Low Serum & $\begin{array}{l}\text { Pooled Low Plus } \\
10 \mathrm{m \mu g} . / \mathrm{ml} . \text { PGA }\end{array}$ & $\begin{array}{l}\text { Recovery of Added PGA } \\
(\%)\end{array}$ & $\begin{array}{l}\text { Pooled Low Plus } \\
20 \mathrm{m \mu g.} / \mathrm{ml} \text {. PGA }\end{array}$ & $\begin{array}{l}\text { Recovery of Added PGA } \\
\text { (\%) }\end{array}$ \\
\hline $\begin{array}{l}1 \\
2 \\
3 \\
4 \\
5 \\
6 \\
7 \\
7 \\
8\end{array}$ & $\begin{array}{l}2.6 \\
2.0 \\
2.8 \\
1.8 \\
2.0 \\
2.4 \\
2.5 \\
2.5\end{array}$ & $\begin{array}{l}15 \cdot 2 \\
10 \cdot 8 \\
13 \cdot 2 \\
14 \cdot 4 \\
13 \cdot 0 \\
14 \cdot 8 \\
13 \cdot 5 \\
14 \cdot 4\end{array}$ & $\begin{array}{r}126 \\
88 \\
104 \\
126 \\
110 \\
124 \\
110 \\
119\end{array}$ & $\begin{array}{l}21 \cdot 6 \\
18 \cdot 0 \\
24 \cdot 0 \\
19 \cdot 2 \\
23 \cdot 0 \\
24 \cdot 0 \\
26 \cdot 0 \\
21 \cdot 2\end{array}$ & $\begin{array}{c}95 \\
80 \\
106 \\
87 \\
105 \\
108 \\
117 \cdot 5 \\
93 \cdot 5\end{array}$ \\
\hline $\begin{array}{l}\text { Mean } \\
\text { S.E. }\end{array}$ & $\begin{array}{l}2 \cdot 3 \\
0.1\end{array}$ & $\begin{array}{r}13.7 \\
0.5\end{array}$ & $\begin{array}{r}113.4 \\
4.7\end{array}$ & $\begin{array}{r}22.1 \\
0.9\end{array}$ & $\begin{array}{r}99 \cdot 0 \\
4.3\end{array}$ \\
\hline
\end{tabular}

TABLE VIII

RECOVERY EXPERIMENTS 
TABLE IX

INTER-ASSAY VARIATION

\begin{tabular}{|c|c|c|}
\hline Assay No. & $\begin{array}{l}\text { 'High' Control } \\
\text { (mug. per ml.) }\end{array}$ & $\begin{array}{l}\text { 'Low' Control } \\
\text { (mug. per ml.) }\end{array}$ \\
\hline $\begin{array}{l}1 \\
2 \\
3 \\
4 \\
5 \\
6 \\
7 \\
8\end{array}$ & $\begin{array}{l}14.8 \\
11.0 \\
12.8 \\
16.0 \\
14.8 \\
14.2 \\
13.2 \\
14.6\end{array}$ & $\begin{array}{l}2 \cdot 6 \\
1 \cdot 6 \\
2 \cdot 4 \\
2 \cdot 0 \\
2 \cdot 3 \\
1 \cdot 7 \\
2 \cdot 0 \\
2 \cdot 8\end{array}$ \\
\hline $\begin{array}{l}\text { Mean } \\
\text { S.E. of mean } \\
\text { Coefficient of variation }\end{array}$ & $\begin{array}{l}13.9 \\
\pm 0.5 \\
10.8 \%\end{array}$ & $\begin{array}{l}2 \cdot 2 \\
\pm 0 \cdot 2 \\
18 \cdot 2 \%\end{array}$ \\
\hline
\end{tabular}

INDEPENDENT DOUBLE DETERMINATIONS These were carried out $(a)$ in the same assay on 47 different sera, and $(b)$ in different assays on 75 different sera.

At the $5 \%$ level of significance, the maximum variation from the mean of two independent determinations on the same sample in the same assay was $\pm 16 \%$, and in different assays $\pm 20 \%$.

We have also shown that there is no significant day-to-day variation in the serum folic acid activity of the same subject. Sera collected from 26 subjects on two consecutive days were assayed in the same batch. The folic acid levels ranged from 2.0 to $25.0 \mathrm{~m} \mu \mathrm{g} . / \mathrm{ml}$., and there was no significant difference between the duplicate samples in each case.

In less than $1 \%$ of cases the variation between the folic acid activity of two consecutive daily serum samples from the same patient greatly exceeded the expected error of the method. In these cases this wide discrepancy between the results was due to exogenous PGA contamination. This was shown in two ways. The contaminated specimen was re-assayed, $(a)$ using Streptococcus faecalis as the assay organism, which responds to PGA, but not to serum folic acid material; and $(b)$ by the standard procedure for $L$. case $i$ without adding ascorbic acid either to the fresh serum or to the phosphate buffer. Under these conditions serum folic acid activity is destroyed, whereas PGA is not.

\section{SERUM FOLIC ACID ACTIVITY IN NORMAL SUBJECTS AND PATIENTS WITH MEGALOBLASTIC ANAEMIA}

The folic acid activity of sera from normal subjects and patients with megaloblastic anaemia measured by this method are given in Table $X$. Each value recorded is the average of two independent assays on two samples taken on consecutive days.

The levels of serum folic acid activity in normal subjects ranged from 5.9 to $21.0 \mathrm{~m} \mu \mathrm{g}$. $/ \mathrm{ml}$. The levels in patients with megaloblastic anaemia due to folic acid deficiency associated with idiopathic steatorrhoea and nutritional folic acid deficiency were less than $3.5 \mathrm{~m} \mu \mathrm{g} . / \mathrm{ml}$.

There was no overlap between the levels obtained in cases of megaloblastic anaemia due to folic acid deficiency and those due to uncomplicated $B_{12}$ deficiency. Of the 42 cases of untreated pernicious anaemia, only one had a folic acid level below the lower limit of the normal range. The folic acid level in this case was $4.0 \mathrm{~m} \mu \mathrm{g} . / \mathrm{ml}$. and the serum $B_{12}$ level $35 \mu \mu \mathrm{g} . / \mathrm{ml}$. This patient failed to respond adequately to treatment with vitamin $B_{12}$ alone and required folic acid as well for a full haematological response.

The mean serum folic acid activity in cases of untreated pernicious anaemia was significantly higher $(P<0.001)$ than in normal subjects. The highest levels of all were found in eight cases of subacute combined degeneration of the cord with only minimal anaemia (range 14.4-36.8 m $\mu \mathrm{g}$. $/ \mathrm{ml}$.; mean $24.8 \mathrm{~m} \mu \mathrm{g} . / \mathrm{ml}$. $\pm 2.4 \mathrm{~m} \mu \mathrm{g} . / \mathrm{ml}$. S.E.). Following treatment with $B_{12}$ the serum folic acid activity fell and there was no significant difference $(0.4>\mathrm{P}$ $>0.3$ ) between the levels of normal subjects and

TABLE X

SERUM L. CASEI ACTIVITY IN VARIOUS CONDITIONS

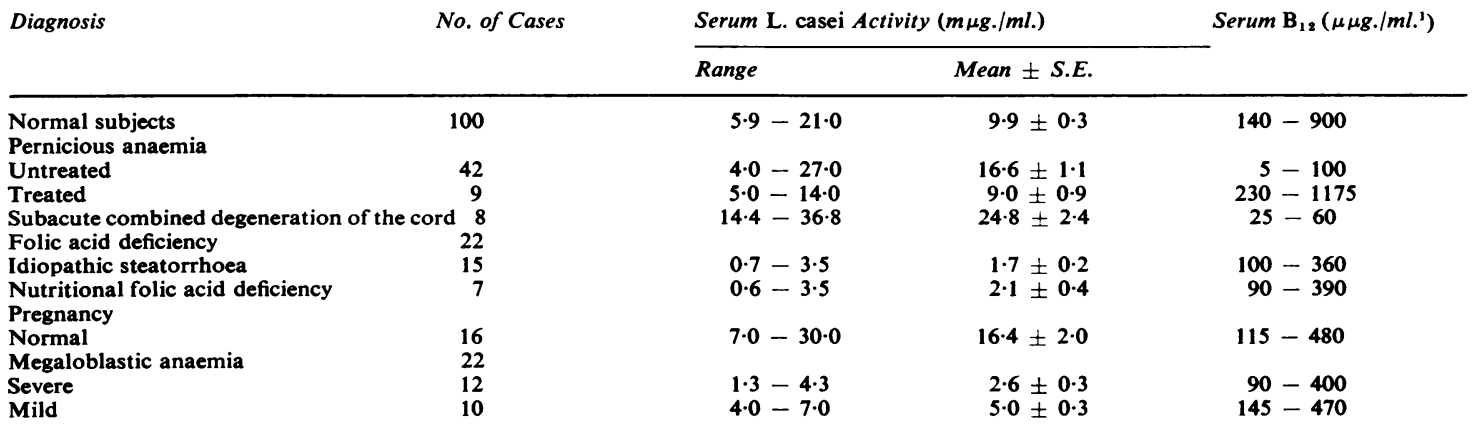

'Euglena gracilis assay (Hutner, Bach, and Ross, 1956). 
cases of pernicious anaemia in remission following treatment with vitamin $B_{12}$.

The mean serum folic acid level in normal pregnant women was significantly higher $(P<0.001)$ than in normal control subjects and not significantly different from the mean level found in cases of untreated pernicious anaemia. In patients with severe megaloblastic anaemia of pregnancy the levels were as low as in cases of severe folic acid deficiency associated with idiopathic steatorrhoea and nutritional folic acid deficiency, but there were also some patients with levels between 4.0 and $7.0 \mathrm{~m} \mu \mathrm{g}$. $/ \mathrm{ml}$. The bone marrow in these cases was only slightly megaloblastic. However, Table $\mathrm{X}$ shows that the mean serum folic acid levels in both of these groups was well below the mean level found in normal pregnant women.

\section{OTHER FACTORS AFFECTING SERUM L. CASEI ACTIVITY}

The effect of antibiotics on serum $L$. casei activity was studied in three patients. Two of these patients had bronchopneumonia. One was being treated with tetracycline, $250 \mathrm{mg}$. q.i.d., when the serum sample was taken, and the other with procaine penicillin, 1 million units daily, and streptomycin, $0 \cdot 5 \mathrm{~g}$. b.d. The third patient, who had puerperal sepsis associated with megaloblastic anaemia, was being treated with chloramphenicol and neomycin, aa $250 \mathrm{mg}$. q.i.d. Moreover, this patient was also receiving pteroylglutamic acid, $25 \mathrm{mg}$. daily. Serum from the two patients receiving tetracycline and chloramphenicol and neomycin inhibited the growth of $L$. case $i$ at a 1:80 dilution, the latter despite the fact that the patient was receiving PGA simultaneously. However, serum from the patient receiving penicillin and streptomycin had an $L$. case $i$ activity in the normal range $(9 \cdot 4 \mathrm{~m} \mu \mathrm{g} . / \mathrm{ml}$.).

The effect of amethopterin was studied in a patient with acute leukaemia, who was being treated with $2.5 \mathrm{mg}$. of amethopterin on alternate days. Serum collected on the days that amethopterin was given inhibited the growth of $L$. casei at a 1:80 dilution, whereas serum collected on the intervening days had a normal $L$. casei activity $(6 \mathrm{~m} \mu \mathrm{g}$. $/ \mathrm{ml}$.).

\section{DISCUSSION}

The results given in this paper suggest that the difficulties we encountered using the assay described by Baker et al. (1959) were mainly due to (1) inadequate protection of the labile folic acid-like material during autoclaving and (2) loss of this material during storage. Our observations suggest that these losses can be prevented by increasing the amount of ascorbic acid in the phosphate buffer and by adding ascorbic acid to serum that is to be stored. When these precautions are taken the variation between the results in different assays is slight and there is a clearcut differentiation between the results in normal subjects and patients with megaloblastic anaemia requiring treatment with folic acid (Table $\mathrm{X}$ ).

PROTECTION OF LABILE FOLIC ACID MATERIAL DURING AUTOCLAVING

The importance of ascorbic acid and of other $\vec{\omega}$ reducing agents for protecting labile folic acid activity of blood during assay has been emphasized by Toennies et al. (1956). For this purpose they in- $\vec{A}$ cluded $50 \mathrm{mg} . \%$ of ascorbic acid in their phosphate buffer and the same procedure was followed by Baker et al. (1959) in assaying serum. The results in 0 Table III of this paper show that these amounts were $\mathrm{S}$ inadequate for serum, but that the protection was complete when amounts of $100 \mathrm{mg}$. \% or more were used. Herbert (1961) has also found it necessary to increase the concentration of ascorbic acid in the buffer.

The role of ascorbic acid is uncertain. The added ascorbic acid presumably is required to protect the labile folic acid material during autoclaving (Toennies et al., 1956). During this process ascorbic acid is also destroyed, but about $40 \%$ remains so that the final concentration in each assay tube was about $0.1 \mathrm{mg}$. per ml. (Dawbarn et al., 1958; Waters and Mollin, 1961). Herbert (1961) reports that ascorbic acid per se may stimulate the growth of $L$. case in in response to PGA. However, he studied the effect using much larger concentrations of folic acid than are used in the assay and with more ascorbic acid, for he did not autoclave the ascorbate-phosphate buffer before its addition to the assay tubes. The results of this paper suggest that under the conditions of the assay the concentrations of ascorbic acid used had no effect on the growth of $L$. casei.

PROTECTION OF LABILE FOLIC ACID MATERIAL DURING N STORAGE OF SERUM

Toennies et al. (1953) pointed out that the folic acid $\stackrel{N}{\omega}$ activity of whole blood dialysates is rapidly lost if stored at $2^{\circ} \mathrm{C}$, but this change did not occur if sera were stored frozen, or with ascorbate-phosphate buffer at $2^{\circ} \mathrm{C}$.

The results here show that there was a considerable $\frac{T}{\circ}$ loss of folic acid activity in serum stored frozen at $\frac{\vec{D}}{\mathbb{D}}$

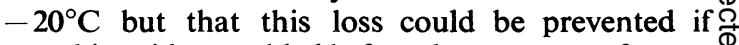
ascorbic acid was added before the serum was frozen. $₫$ The apparently 'lost' folic acid activity could be restored by adding ascorbic acid to previously stored $\delta$ serum (Table VII). To do this, larger concentrations? 
of ascorbic acid appear to be required than are needed to protect the material during autoclaving.

NATURE OF THE L. CASEI ACTIVE MATERIAL IN SERUM

The nature of the stable and labile folic acid material in serum is unknown. Although blood contains a number of factors with folic acid activity, neither pteroylglutamic acid nor citrovorum factor are present (Usdin, 1959).

The stable material resembles in certain respects pteroylglutamic acid, for it is active for $L$. case $i$, Strep. faecalis, and L. citrovorum, but other folic acid compounds and nucleotides also have similar characteristics. Furthermore, the fact that the concentrations of stable material in the serum of patients with pernicious anaemia and folic acid deficiency are similar to those found in normal subjects suggests that it is unlikely that this material is pteroylglutamic acid.

The labile folic acid factor resembles in some respects a precursor of citrovorum factor. It has been shown that ascorbic acid protects a labile precursor of folinic acid which appears in urine after the ingestion of folic acid (Silverman, Ebaugh, and Gardiner, 1956). However, the labile component in serum is not converted into folinic acid by autoclaving in the presence of ascorbic acid, because the folic acid material in serum has very little growth activity for Leuconostoc citrovorum (Pedicoccus cerevisiae) or Streptococcus faecalis (Toennies et al., 1953; Usdin, 1959; Herbert, 1961; Waters and Mollin, unpublished observations), and Baker et al. (1959) and Herbert (1961) have suggested that it may well be a polyglutamate.

The significance of the increase in labile $L$. case $i$ active material in untreated Addisonian pernicious anaemia and normal pregnant women is uncertain. The material presumably accumulates either because it is formed in excessive amounts in these patients or because there is a defect in its utilization. This observation is particularly interesting in view of the fact that injected pteroylglutamic acid is removed more rapidly from the plasma of patients with severe untreated pernicious anaemia than from normal subjects (Chanarin, Mollin, and Anderson, 1958). It was also found by Chanarin, MacGibbon, O'Sullivan, and Mollin (1959) that the mean plasma clearance of injected pteroylglutamic acid was more rapid in normal pregnant women than in normal control subjects.

\section{OTHER MODIFICATIONS OF THE ASSAY PROCEDURE}

The method described differs in certain other respects from that described by Baker et al. (1959).
1 Enzymatic casein hydrolysate is used instead of salt-free acid hydrolysed casein. This was used because with acid hydrolysed casein some precipitation occurred in the medium during autoclaving and this led to a high blank reading. A similar precipitation was observed with B.B.L. 'dry-mix' medium which, however, was otherwise very satisfactory.

2 The final volume in each assay tube was reduced from $10 \mathrm{ml}$. to $4 \mathrm{ml}$., and a final serum dilution of $1 / 80$ was used. As a result of these changes only $0.5 \mathrm{ml}$. of serum was required for the assay and the range of serum folic acid activity that could be measured accurately was 2.0 to $20.0 \mathrm{~m} \mu \mathrm{g}$. $/ \mathrm{ml}$., compared with 3.0 to $30.0 \mathrm{~m} \mu \mathrm{g}$. $/ \mathrm{ml}$. by the method of Baker et al. (1959), who used a final serum dilution of 1/100. Cooperman, Luhby, and Avery (1960) have recently described a method of assay with $L$. case i in which the assay volume was reduced to $2 \mathrm{ml}$.; however, the overall sensitivity of this method was reduced by the very high serum dilutions which they used $(1 / 250$ to $1 / 1,000)$; the lower limit of serum folic acid activity that could be measured accurately at their lowest dilution being $3.75 \mathrm{~m} \mu \mathrm{g}$. $/ \mathrm{ml}$.

3 INCUBATION BEFORE ASSAY In the method described by Toennies et al. (1956) blood, after dilution with the ascorbate-phosphate buffer $(50 \mathrm{mg}$. $\%$ ascorbic acid), was incubated for 90 minutes at $38^{\circ} \mathrm{C}$. before autoclaving, and this procedure was followed by Baker et al. (1959). This was found to be unnecessary if the serum was assayed within 48 hours of collection or if it had been stored with added ascorbic acid or if the lost folic acid activity of stored serum was restored by the addition of relatively large amounts of ascorbic acid. Herbert (1961) also found that incubation of the serum-ascorbic acid-buffer solution did not increase the folic acid activity of (presumably) fresh serum.

\section{CLINICAL VALUE OF THE ASSAY}

The results in Table $\mathrm{X}$ confirm the claim of Baker et al. (1959) and of Herbert, Baker, Frank, Pasher, Sobotka, and Wasserman (1960) that the $L$. case $i$ assay is a valuable means of differentiating patients with megaloblastic anaemia requiring treatment with folic acid from patients with vitamin $\mathbf{B}_{\mathbf{1 2}}$ deficiency. In patients with megaloblastic anaemia due to idiopathic steatorrhoea or dietary folic acid deficiency, the concentrations were invariably below the normal range. Similar results were also found in patients with severe to moderate megaloblastic anaemia of pregnancy. However, borderline levels were found in some patients with moderate to mild megaloblastic anaemia of pregnancy, but these were 
below the levels found in normal pregnant women. Borderline levels were also found in one patient with pernicious anaemia who failed to respond adequately to treatment with $\mathrm{B}_{12}$ alone. In cases of uncomplicated $B_{12}$ deficiency the levels were higher than normal and the highest levels of all were found in cases of subacute combined degeneration of the cord with minimal anaemia.

We have also observed that, when treatment with folic acid is stopped in patients with folic acid deficiency, megaloblastosis will reappear in the marrow while the serum $L$. casei concentration is still within the normal range (Waters and Mollin, unpublished observations). This suggests that the level of $L$. casei active material in serum is in part a function of the duration of the folic acid deficiency.

It is a great pleasure to thank Professor J. V. Dacie for his interest and advice, and Dr. C. C. Booth for his help in the investigation and management of the patients studied in this paper, many of whom were under his care. We should also like to thank the physicians at the Hammersmith Hospital; Dr. N. F. Coghill and Dr. J. S. Selwyn of the West Middlesex Hospital; Dr. K. Dormandy of the Hospital for Sick Children, Great Ormond Street; and Dr. N. Richardson of the Epsom District Hospital, Surrey, for permission to study their patients.

We are indebted to Dr. D. Alldis for the ascorbic acid estimations, and Dr. W. L. Williams of Lederle Laboratories Inc. for a supply of crystalline pteroylglutamic acid.

We also thank Mrs. S. Lichtigfeld and Miss R. Smith for assistance with the microbiological assays.

\section{REFERENCES}

Baker, H., Herbert, V., Frank, O., Pasher, I., Hutner, S. H., Wasser- $\overrightarrow{\bar{F}}$ man, L. R., and Sobotka, H. (1959). Clin. Chem., 5, 275.

Chanarin, I., Anderson, B. B., and Mollin, D. L. (1958). Brit, J. Haemat., 4, 156

—, MacGibbon, B. M., O'Sullivan, W. J., and Mollin, D. L. (1959). Lancet, 2, 634.

-, Mollin, D. L., and Anderson, B. B. (1958). Ibid., 4, 435.

Condit, P. T., and Grob, D. (1958). Cancer, 11, 525.

Cooperman, J. M., Luhby, A. L., and Avery, C. M. (1960). Proc. Soc. ڤొ exp. Biol. (N.Y.), 104, 536.

Cox, E. V., Meynell, M. J., Cooke, W. T., and Gaddie, R. (1960). $\vec{\circ}$ Clin. Sici., 19, 219.

Dawbarn, M. C., Hine, D. C., and Smith, J. (1958). Aust. J. exp. Biol. med. Sci., 36, 511 .

Girdwood, R. H. (1953). Blood, 8, 469.

Grossowicz, N., Aronovitch, J., Rachmilewicz, M., Izak, G., Sadovsky, A., and Bercovici, B. (1960). Brit. J. Haematol., 6, 296.

Herbert, V. (1961). J. clin. Invest., 40, 81.

-, Baker, H., Frank, O., Pasher, I., Sobotka, H., and Wasserman, L. R. (1960). Ibid., 15, 228.

Hutner, S. H., Bach, M. K., and Ross, G. I. M. (1956). J. Protozool., $3,101$.

Jukes, T. H. (1955). Meth. biochem. Anal., 2, 121.

Nieweg, H. O., Faber, J. G., de Vries, J. A., and Kroese, W. F. S. (1954). J. Lab. clin. Med., 44, 118.

Schweigert, B. S. (1948). ibid. 33, 1271.

- , and Pearson, P. B. (1947). Amer. J. Physiol., 148, 319.

Silverman, M., Ebaugh, F. G., and Gardiner, R. C. (1956). J. biol. Chem., 223, 259.

Simpson, R. E., and Schweigert, B. S. (1949) Arch. Biochem., 20, 32.

Spray, G. H. (1952). Clin. Sci., 11, 425.

-, and Witts, L. J. (1952). Ibid., 11, 273.

Stamp, Lord (1947). J. gen. Microbiol., 1, 251.

Stokstad, E. L. R., Fordham, D., and Grunigen, A. de (1947). J. biol. Chem., 167, 877.

Toennies, G., and Gallant, D. L. (1949). J. Lab. clin. Med. 34, 501. \) Frank, H. G., and Gallant, D. L. (1953). J. biol. Chem., 200, 23. , Usdin, E., and Phillips, P. M. (1956). Ibid., 221, 855.

Usdin, E. (1959). Ibid., 234, 2373.

Waters, A. H., and Mollin, D. L. (1961). Unpublished observations. Wolff, R., Drouet, L., and Karlin, R. (1949). Bull. Soc. chim. Biol., 31, 265. 